International Business and Global Economy 2017, no. 36, pp. 31-46

Biznes międzynarodowy w gospodarce globalnej 2017, nr 36, s. 31-46

Edited by the Institute of International Business, University of Gdańsk

ISSN 2300-6102

e-ISSN 2353-9496

DOI 10.4467/23539496IB.17.002.7450

Katarzyna Kubiszewska

Politechnika Gdańska

\title{
Financial comparison of Western Balkan and Baltic Sea states using the CAMEL approach
}

This article aims to compare the situation in the banking sectors of two regions that have much in common due to their political and economic history: the Western Balkan states of Serbia, Croatia, and Macedonia and the Baltic Sea states of Lithuania, Estonia, and Latvia. It presents three approaches to defining banking stability that can be found in literature and carries out a preliminary analysis of the financial performance of the discussed banking sectors using the CAMEL approach. Although in 2010 the banking sectors of the Baltic Sea states were in a worse shape than the banking sectors of the Western Balkan states, it has been proved that the banking sectors in countries in which the process of economic transformation has been completed could recover from a crisis faster than states that are still undergoing this process. Economic transformation is essential for the further development of the market economy and the sooner it is completed, the sooner the banking sector can develop and the easier it will be to recover from a crisis or an external shock.

Keywords: banking sector stability, CAMEL approach, Baltic Sea states, Western Balkan states JEL classification: G10, G20, G21

\section{Porównanie sytuacji w sektorach bankowych w regionie Bałkanów Zachodnich i krajów bałtyckich przy wykorzystaniu systemu CAMEL}

Celem artykułu jest porównanie sytuacji sektorów bankowych w dwóch regionach, które ze względu na doświadczenia polityczne i gospodarcze mają wiele wspólnych cech: Serbii, Chorwacji i Macedonii w regionie Bałkanów Zachodnich oraz Litwie, Łotwie i Estonii w regionie nadbałtyckim. Opierając się na literaturze, zaprezentowano trzykierunkowe podejście do definiowania stabilności sektora bankowego. Przy użyciu systemu CAMEL przeprowadzono również wstępną analizę sytuacji finansowej wybranych sektorów bankowych. Mimo iż w 2010 roku sytuacja w sektorach bankowych państw bałtyckich była gorsza niż w sektorach bankowych państw Bałkanów Zachodnich, udowodniono, że sektory bankowe w krajach, w których proces transformacji gospodarczej dobiegł końca, mogłyby szybciej wyjść z kryzysu w porównaniu do państwami, które są jeszcze w trakcie tego procesu. Transformacja gospodarcza ma zasadnicze znaczenie dla dalszego budowania gospodarki rynkowej, a im szybciej zostanie zakończona, tym szybciej sektor bankowy będzie mógł się rozwinąć i tym łatwiej będzie odbudować pozycję po kryzysie lub wstrząsie zewnętrznym.

Słowa kluczowe: stabilność sektora bankowego, system CAMEL, kraje bałtyckie, Bałkany Zachodnie Klasyfikacja JEL: G10, G20, G21 


\section{Introduction}

The banking sector plays a crucial role in the economy, supporting it with funds essential for development and growth. Its stability is therefore vital for the economy as a whole. There are various definitions of banking sector stability, which all explain the basic requirements that must be met in order for the banking sector to be stable. There is no universal definition of this concept, and the existing explanations can be divided into three groups: those that define stability in terms of (1) the banking sector's influence on the macroeconomic situation, (2) the quality of the banking sector, and (3) the absence of a crisis.

The aim of this article is to compare the stability of two groups of banking sectors. The first group comprises the Western Balkan states of Macedonia, Croatia, and Serbia, and the second - the Baltic Sea states of Estonia, Latvia, and Lithuania. The tools used to analyse the financial situation in the selected countries are the CAMEL system and an adapted version of the Macroeconomic Stabilisation Pentagon. The article was also based on a study of documents and a critical analysis of the literature.

\section{Banking sector stability: Literature review}

\subsection{Banking stability and the macroeconomic situation}

Banking stability can be defined as being influenced by the links between financial stability and the macroeconomic situation. The impact of banking sector development on economic development is the subject of numerous studies. Many researchers confirm the importance of finance for economic growth [King, Levine, 1993; Claessens, Laeven, 2003; Levine, 2005; Larrain, 2006; Raddatz, 2006]. Others do not overestimate its influence [Lucas, 1988]. It has been noted that banking market turbulence have a negative impact on economic growth due to reduced lending [Kroszner, Laeven, Klingebiel, 2007; Dell'Ariccia, Detragiache, Rajan, 2008] and changes in the type of investments [Fernández et al., 2013]. It seems reasonable to claim that ensuring the stability of the financial system is a prerequisite for meeting all traditional purposes of the economy, while banking instability presents a considerable risk to the domestic economy [Kalemli-Ozcan, Papaioannou, Perri, 2013], particularly as it often precedes even more costly currency and debt crises [Reinhart, Rogoff, 2009; Laeven, Valencia, 2013].

Numerous studies draw attention to the close relationship between the stability of the banking system and the monetary and economic policy. Djiwandono [1998] claims that neither an efficient monetary policy nor a well-executed eco- 
nomic policy cannot be properly implemented without a healthy banking system. It is also argued that banking stability should be the focus of monetary and price policy. Guitian [1997] also believes that stability of the banking system is a component of monetary and economic policy. At the same time, as a matter of policy, the banking system should strive toward economic balance and stability. An unhealthy banking system translates into weak monetary transmission and thus an ineffective monetary policy [Lingren, Garcia, Saal, 1996]. Banking instability may be a result of an unsustainable monetary environment, as the activities of banks in an economy struggling with inflation are not efficient. It also means that a healthy banking system is essential for the effective transmission of signals between monetary policy and market participants. The effectiveness of central bank operations depends on how the banking system transfers funds to borrowers and lenders. The impact of the central bank on market and financial stability was studied by Żywiecka [2012]. Gemzik-Salwach [2013] studied the relation between the stability of the banking sector and a public finance crisis.

The dependence of other economic sectors on the banking system proves its importance for the whole economy, which is also illustrated by the influence exerted on it by the insolvency of countries [Smaga, 2012]. A stable and healthy banking system combined with balanced public finances may contribute to the stability of the whole economic system.

\subsection{Banking stability and the quality of the banking sector}

The stability of the banking system can also be a measure of its quality. Since banks constitute the basis of the financial system, the security and well-being of a country depend largely on the stability of the banking system. Problems encountered by banks are expensive for the state, both from a financial as well as an economic perspective, because they can easily spread from one country to other countries and their markets. Moreover, the stability of the banking system corresponds to the fulfilment of its basic functions, which ensures an efficient cash flow between the participants thanks to the proper valuation of assets, stability of prices, and security and efficiency of payment runs. In a healthy banking system, individual banks effectively mediate financial transactions and, at the same time, meet the capital requirements set by the law. If the banking system is to remain stable and solvent in the long term, individual banks must be profitable, well managed, and effective.

The literature abounds with discussions regarding the impact of banking sector stability. One view is that too much competition may destabilise financial markets and credit institutions, although competition as such does not create instability. Systemic risk may arise irrespectively of the character of competition and in different market structures [Vives, 2010; Staikouras, Wood, 2000; Fernández, Garza-Garcia, 
2015]. It is also increasingly emphasised that stronger competition not always causes stability and efficiency to deteriorate, as an adequate deposit protection policy (e.g. the creation of a deposit protection fund) may have a stabilising effect on the relationship between competitiveness and stability. The existing literature also discusses potential conditions that may positively affect banking stability, namely stronger regulatory capital [Acharya, Drechsler, Schnabl, 2010; Berger, Bouwman, 2013; Cole, 2012; Miles, Yang, Marcheggiano, 2013], larger banking sector and higher market concentration [Allen, Gale, 2000; Beck, Demirguc-Kunt, Levine, 2006; Bretschger, Kappel, Werner, 2012; Mirzaei, Moore, Liu, 2013], and reduced activity in the shadow banking sector [De Jonghe, 2010; Lepetit et al., 2008].

\subsection{Banking stability and the absence of a crisis}

Banking stability is most frequently defined in the literature as the absence of a financial crisis. However, even such a narrow definition raises a lot of doubts due to the heterogeneity in the understanding of the term 'financial crisis'. On the one hand, there is virtually no definition in classic literature on financial crises; on the other, empirical studies indicate the existence of many different definitions, the synthesis of which must, therefore, be of a fairly general character.

There are two approaches to financial crises. In the narrower one, shaped by monetarists, a financial crisis is associated with a bank run. A bank run results in disturbances in the money supply, which leads to a decline in economic activity. Lower asset prices and a rising number of corporate bankruptcies do not in themselves constitute a financial crisis. Such a state is referred to in the literature as a 'financial pseudo-crisis'. The wider approach to financial crises defines the concept as a situation in which at least one of the following factors occurs: falling asset prices, bankruptcy of large financial and non-financial institutions, deflation or lower inflation, and foreign exchange market turmoil. Bordo and Eichengreen [1999] deem a financial crisis as a series of rapid changes in the financial market connected with the scarcity of liquidity and insolvency of market participants as well as the possibility of government intervention designed to prevent a financial crisis. Allen and Wood [2006] define it as a situation in which the debtor is unable to repay his debts and cannot in any way obtain additional financing. The spread of a financial crisis from a single entity to many participants is reflected in the disturbance in the performance of the basic functions of the system. As a consequence, disturbances in the payment system and in the process of allocating financial resources and sudden unpredictable changes in asset prices occur. Davis [2001] considers a financial crisis as a process leading to macroeconomic depression, mass bankruptcy of financial institutions, and disfunctioning of the payment system. On the other hand, Crockett [1997] claims that the absence of banking stability should not be confused with a crisis and defines the former as a state in 
which economic activity is not affected by changes in asset prices or by the problems of financial institutions in meeting their obligations. He notes that periods of rises or falls in asset prices, as well as bankruptcies of individual institutions, are an inherent feature of economic life.

\section{Research methodology}

The CAMEL approach has been chosen to carry out a comparative analysis of the financial situation of banks in the selected groups of banking sectors. CAMEL is a system of ratios created in the US in the 1980s [Bauer et al., 1998]. These ratios are related to the studied market's capital, quality of assets, management, profitability, and liquidity [Cox, Cox, 2006]. This approach has not yet been used in studies of the banking sectors of the Western Balkan states or the Baltic Sea states. Therefore, the purpose of this article is to fill this gap in the literature and use the CAMEL approach to compare these two groups of sectors, which had to face relatively similar problems on their path from a centrally planned to a market economy. The following ratios have been chosen for the analysis conducted in this paper: Capital Adequacy Ratio, Non-Performing Loans to Total Loans, Personnel Expenses to Non-Interest Expenses, Return on Assets, and Liquid Assets to Total Assets. The analysis will cover a period of five years between 2010 and 2015 a time of transformation within the banking sectors, during which the countries were coping with a financial crisis that affected the local banking sectors through indirect channels.

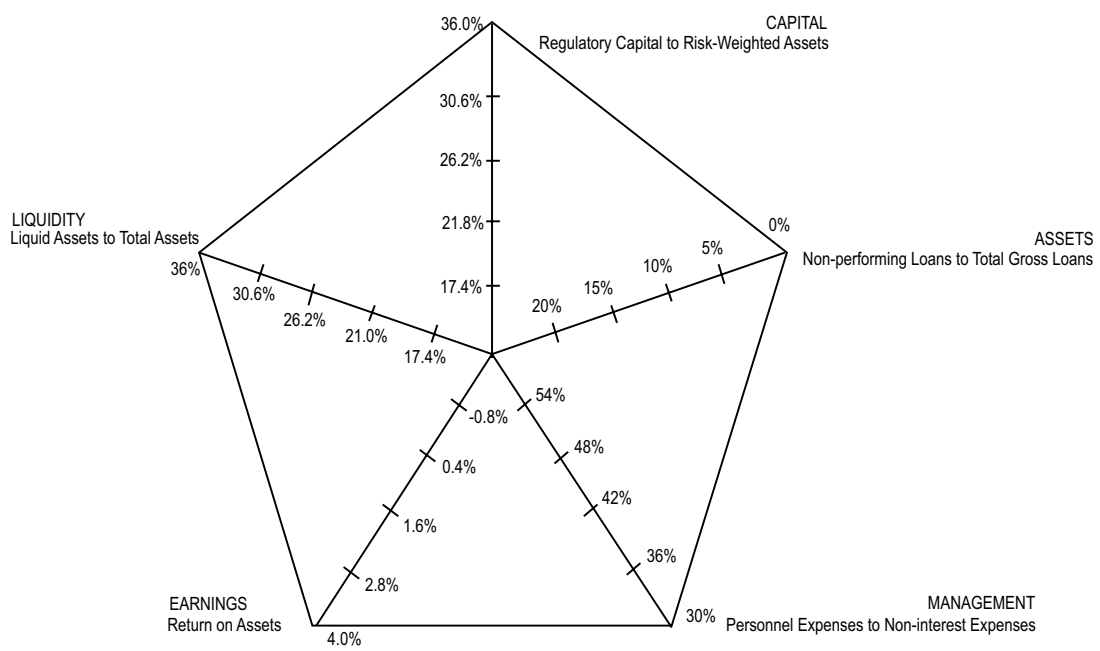

Figure 1. Pentagon of the CAMEL system

Source: Own elaboration. 
To present the results of the analysis in a more transparent way, the concept of the Macroeconomic Stabilisation Pentagon, created by the Institute for Market, Consumption, and Business Cycles Research, has been used and adapted. As shown in Figure 1, each of the vertices of the pentagon, which display the main macroeconomic indicators, have been replaced with the ratios from the CAMEL system, each representing one crucial part of the analysis: Regulatory Capital to Risk-Weighted Assets (representing Capital), Non-Performing Loans to Total Gross Loans (representing Assets), Personnel Expenses to Non-Interest Expenses (representing Management), Return on Assets (representing Earnings), and Liquid Assets to Total Assets (representing Liquidity).

\section{The characteristic of the studied states}

The study aims to compare countries from two regions of Europe: the Western Balkan states of Macedonia, Serbia, and Croatia and the Baltic Sea states of Estonia, Lithuania, and Latvia. They are characterised by certain common features they had to fight for their identity and build their statehood from scratch. In the case of the Baltic Sea states, this process was relatively peaceful, but the Western Balkan countries remained in conflict for much of the 1990s.

Moreover, all of them decided to transform their economies into market economies. The term 'transformation' comes from Latin and means 'conversion' [Blok, 1993, p. 8]. Since the literature does not clearly define the concept of transformation, it must be stressed that it refers not only to the economic system, but to civilisation as a whole [Chołaj, 1998, p. 342]. In the economic dimension, transformation involves creating entities that operate in market conditions and accomplish their objectives in the spirit of freedom and respect for individual rights [Bałtowski, Miszewski, 2006, p. 24]. Transformation may be also identified with establishing infrastructure that is characteristic of a market system [Bromley, 1993]. In this article, transformation is associated with privatisation, establishing a new legal system, and creating institutions governed by market principles. This obviously affected the banking sectors as well.

Apart from having a common history, all of the studied countries can see their future connected with the European Union. Not only have the Baltic Sea states been EU members since 2004, but they have also recently joined the eurozone (Estonia in 2011, Latvia in 2014, and Lithuania in 2015). By adopting the common currency, these countries decided to give up independent monetary policy and now largely depend on the ECB's policy. They joined the eurozone when the ECB's actions were concentrated on ensuring the stability of the banking sector, and not the price system. Interest rate rises were revoked - in November and December 
2011 they were reduced to record levels and further lowered in July and May 2013 and June and September 2014. As part of the new Outright Monetary Transactions program, the ECB continued buying eurozone bonds, whose yields began to rise sharply, and introduced credit facility packages. In 2014, the ECB's monetary policy focused on two directions: creating an appropriately expansive attitude under conditions of low inflation and economic stagnation as well as improving the transmission process to make it felt by enterprises and households.

The Western Balkan countries are also engaged in the integration process. Croatia joined the EU in June 2013, but it has been a candidate state since 2003. In June 2011, accession negotiations were closed and according to the Croatia 2011 Progress Report [EC, 2011], Croatia's legislation regarding financial market infrastructure already fulfilled the acquis requirements. Macedonia earned the status of a candidate country in 2006 and Serbia - in 2012. This means that these states still need to adjust their legal system, including the banking system, to the European requirements. In 2013, the Central Bank of Macedonia introduced a procedure for determining the banking stability index and developed a methodology for identifying systemically important banks. In 2015, it developed a new methodology for evaluating the Bank's Internal Capital Adequacy Assessment Process (ICAAP) and amended the legislation in the areas of capital adequacy and liquidity risk management. A year later the law was further amended to comply with the new Basel principles for effective banking supervision and specifying capital buffers [EC, 2014a; 2015a; 2016a]. Step by step, Serbia is adjusting its financial system to the European standards by introducing the Law on Accounting, the Law on Deposit Insurance, and the Law on the Deposit Insurance Agency, as well as devising a plan for the implementation of Basel III standards by 2017. The administrative capacity of the Banking Supervision Department of the National Bank of Serbia was strengthened [EC, 2014b; 2015b; 2016b]. What is more, the monetary regimes differ between the Balkan countries just as they do between the EU members: Croatia and Serbia introduced a managed float, and Macedonia - pegs against the euro [EBRD].

Another similarity between the studied countries is the structure of their banking sectors. Not only do they have a similar number of credit institutions (around 30, with the exception of Macedonia and Lithuania, which have 15 banks each), but they are also highly penetrated by foreign investors and highly concentrated (in 2015, CR5 reached 72\% in Latvia, 98\% in Lithuania and Estonia, 62\% in Serbia, $76 \%$ in Croatia, and $82 \%$ in Macedonia). The only difference is the source of the foreign capital, which in the Baltic Sea states comes from Scandinavia, and in the Western Balkans - from Italy, Austria, and Germany. This is the heritage of their previous economic relationships, which date even from the 1970s. The Yugoslavian Republic has been willingly cooperating with neighbour countries, e.g. 
Austria and Italy [Jovanovic, 1972, p. 587]. Such a strong dependence on foreign investors resulted in the spillover of the global financial crisis, which reached the Western Balkan region through indirect channels [Bartlett, Monastiriotis, 2010; Sen, Atlay, 2012]. The annual rate of credit growth in these countries dropped significantly. The new wave of turbulence resulted from the 2011 post-crisis risk aversion in the eurozone. Great hopes were placed in the Vienna II initiative launched in March 2012. Unfortunately, it could only reduce the pace of the withdrawal of funds from the region. Within three years, between 2011 and 2014, an equivalent of ca. $8 \%$ of the region's GDP in external bank funds was transferred to the European headquarters of local banks. Investing banking groups continued to operate in the region, but on a smaller scale [Sanfey, Milatović, Krešić, 2016, p. 36].

The key difference between the otherwise similar structures of the two groups of studied banking markets is their size, which is the consequence of the delayed beginning of the transformation process in the Western Balkan states.

\section{Results of empirical research}

Figure 2 illustrates the performance of the studied countries in 2010 and 2015 as well as the average index values for both studied regions of Europe: the Western Balkan and the Baltic Sea states.

The first general conclusion which can be drawn from the analysis is that the Baltic Sea states (BSS) made more progress in transforming and developing their banking sectors than the Western Balkan states (WBS). In 2010, the former were in a worse shape. They suffered losses indicated by a negative Return on Assets (ROA) ratio. In terms of quality of assets, their ratio of non-performing loans (NPL) to total loans was on average higher (by 5pp) than in the WBS. Liquidity was lower by $50 \%$, and personnel expenses increased by $4 \mathrm{pp}$ in relation to noninterest expenses. However, after five years, the significant achievements of the BSS banking sectors raised them to a level comparable to the WBS. In terms of earnings, quality of assets, and quality of capital, the BSS outmatched the other region. The difference in results was not significant, but still visible: $1 \mathrm{pp}$ in ROA, 8pp in ratio of NPL to total loans, and 4pp in capital adequacy ratios (CARs). The values of other two indices, namely the ratio of personnel expenses to non-interest expenses and liquidity, remained better in the WBS (lower by almost 12pp and higher by 4pp, respectively). Unfortunately, their progress cannot be considered significant.

Croatia and Serbia achieved CARs of ca. 20\%. Only in Macedonia this ratio was below $17 \%$. The quality of banking assets, as evaluated based on the ratio of NPL to total gross loans, is rather poor, which attests to the increasing risk of debtors 


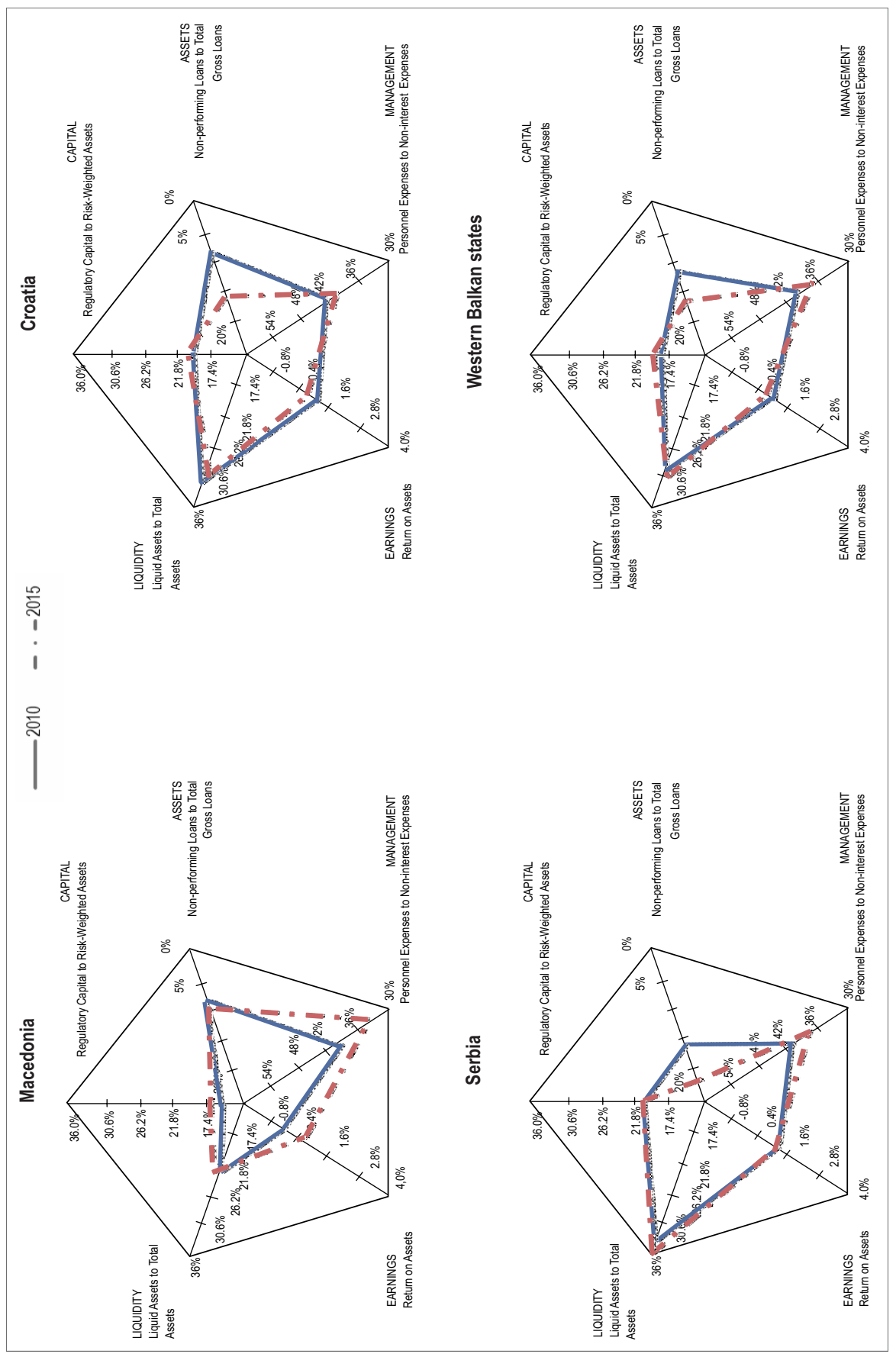




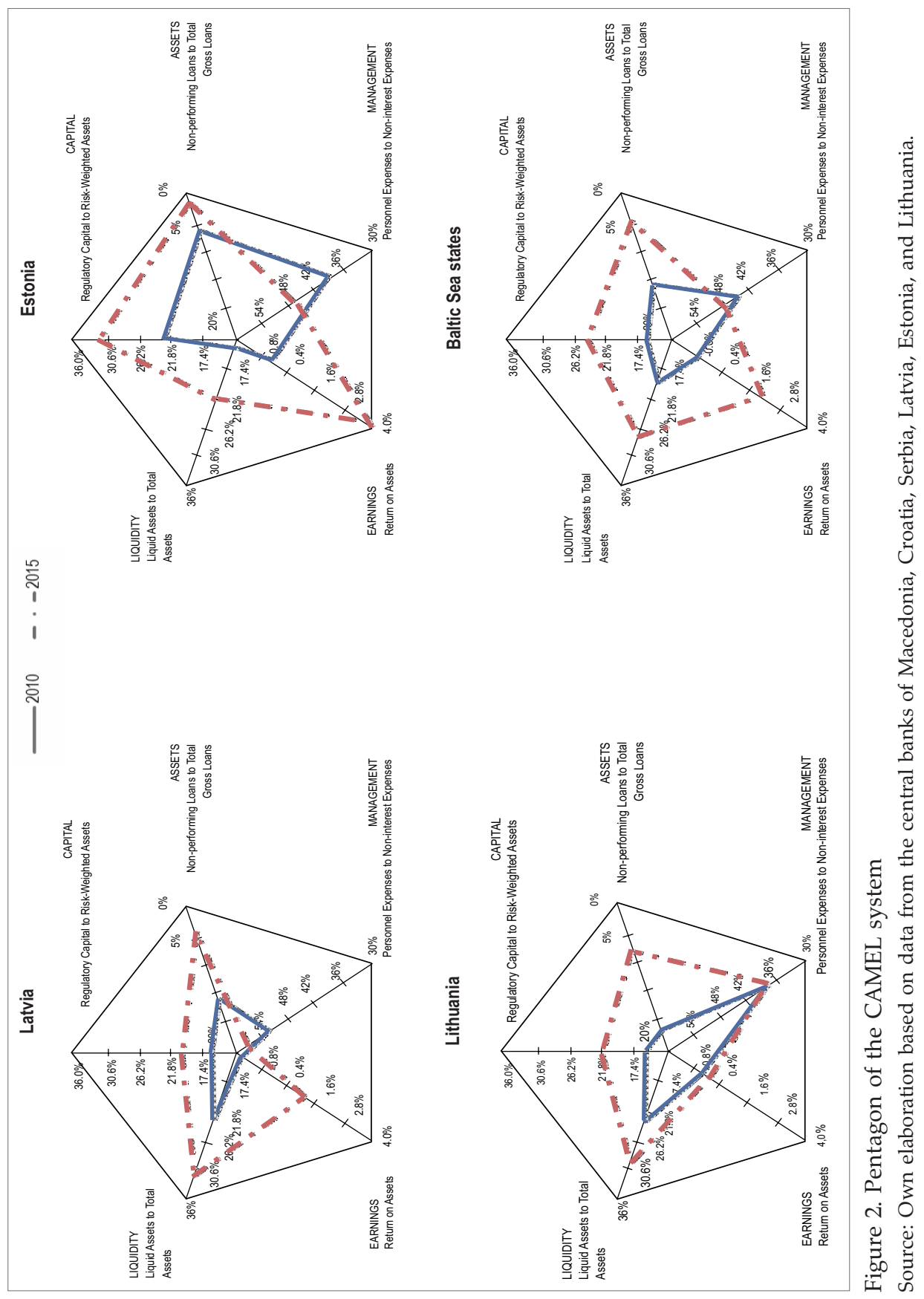


not repaying their loans, most probably because of their unfavourable economic performance. Moreover, this ratio increased by $14 \%$ in Macedonia and nearly doubled in Croatia. The highest level of the ratio, exceeding $22 \%$, was recorded in 2015 in Serbia. In terms of management, the falling share of personal expenses to non-interest expenses on the one hand shows the positive effect of the adopted financial policies, but on the other it can be considered as a tool for improving the overall situation in the sector, while the final effect of such changes is moot. However, the important thing is that, throughout the whole studied period, the banking sectors in the WBS were profitable but with a decreasing ROA. They also remained liquid, with a high liquid asset ratio at $30 \%$.

In 2010, the BSS were in a much worse state compared to the WBS, but by adopting reasonable fiscal policies their banking sectors were able to restore fiscal sustainability. Latvia can be considered as having the best practice for recovering from deep economic crisis, including honest communication of the real situation to the population, early action taken to restore confidence, implementation of fiscal adjustment, expenditure cuts (instead of tax increases) driving structural reforms, equity requirements, and obtaining international rescue financing. Estonia's economic advantages stems from its transparency and economic freedom (which earned it sixth place globally and second in Europe in this scope [Transparency International, 2016]). An independent and efficient judicial system monitors the rule of law. Its other benefits include a simplified tax system, flat tax rates, low indirect taxation, and a liberal trade regime, all of which attract foreign investors [Cole, Pomerleau, 2015], as well as investments in the IT sector and implementation of its solution in practice, e.g. in public service (thanks to which filing a tax return takes less than five minutes and $98 \%$ of banking transactions are conducted online). Estonia is recognised as the third country with the lowest business bribery risk in the world [TRACE International, 2016].

The BSS banking sectors did not adequately support the economic recovery, but profited from the improved situation. Due to the capital requirements Latvia and Lithuania had CARs below $14 \%$, which was still much lower compared to the other studied banking sectors. Over the five years, the ratio increased to $20 \%$, proving increased protection of depositors and stability and efficiency of the banking sectors. In 2010, the quality of banking assets was very poor as a result of the unfavourable economic situation brought about by the financial crisis of 2008 . The highest ratio (over 23\%) was recorded in Lithuania. After five years, the overall economic situation improved and the ratio dropped to the acceptable level of $1.2 \%$ in Estonia and $8.2 \%$ in Lithuania.

The share of personal expenses increased by 3pp in the WBS and even more in Latvia (from $52 \%$ to over $60 \%$ ) and Estonia (from $39 \%$ to $46 \%$ ). The other negative performance indicator was the unprofitability of the banking sectors in 2010 . 
In each country they recorded a negative ROA (-0.3\% in Estonia and over $-1.8 \%$ in Latvia). The implemented recovery plans improved the economic situation, which resulted in an increase in ROA by over 3pp to $1.35 \%$ in Latvia and $3.6 \%$ in Estonia. The liquid asset ratio increased by almost $40 \%$ in each country in the region over the studied period. The work done in 2009-2012 to improve credit quality in loan portfolios and strengthen the capital base in the BSS banks made them more resilient to financial difficulties.

In 2010, all of the studied countries had similar CARs, although in each group of banking sectors there was one where the ratio was slightly higher (in the WBS it was Serbia with $20 \%$ and in the BSS it was Estonia with over $23 \%$ ). The same situation occurred in 2015, but the ratios were significantly higher (over 33\% in Estonia and over $20 \%$ in two countries in the Western Balkans). In terms of quality of assets, the ratio of NPL to total gross loans further increased in the WBS. In Macedonia and Croatia, the value of NPL never exceeded 17\%, and a significant upward trend in terms of the value of NPL could be seen in this region. The highest ratios were recorded in Serbia. This demonstrates that, as a consequence of the global crisis, the economic situation is unfavourable and may affect the situation in the banking sectors. The factors which limit the credit supply are banks' capital and non-performing loans. As barriers to credit supply, domestic factors play a less important role than global factors. The former include regulatory environment and bank's capital, and the latter - global market outlook, EU regulations, group-level NPLs, and group-level capital constraints.

Over the studied period, the situation in the BSS improved. The ratio of NPL to total gross loans decreased, although in 2010 in Latvia and Lithuania it was significantly higher than in other countries (almost 16\% and 24-25\%, respectively). Estonia is the only country where the ratio never exceeded 6.5\%. The very high immediate post-crisis peak was reduced relatively quickly thanks to comprehensive reforms.

When it comes to employee management, the ratio of personal expenses to non-interest expenses can be used to illustrate the quality and skills of the staff working in the banking sectors. The higher the ratio, the more is spent on employees. In this aspect, the leader is Latvia, where personal expenses amount to more than half of non-interest expenses, increasing from 52\% in 2010 to $60 \%$ in 2015. In Macedonia these expenses not only were the lowest but also presented were a downward trend (from 37\% in 2010 to nearly 31\%). In the other two Balkan countries the ratio decreased as well (by $2 \mathrm{pp}$ in Croatia and by $4 \mathrm{pp}$ in Serbia). The ratio increased by 7pp in Estonia, while in Lithuania it remained very stable at 37-38\% .

The above analysis attests to the better achievements of the BSS banking sectors. The ROA ratio shows how efficiently the management of an institution is able to convert resources into results. This ratio increased significantly in the BSS 
(from $-0.8 \%$ to $1.7 \%$ ), while decreasing by $0.11 \mathrm{pp}$ in the WBS (from $0.88 \%$ to $0.77 \%$ ). It should be mentioned that Latvia suffered the most from the global financial crises [Klyvienë, Tranberg Rasmussen, 2010, pp. 7-27], even compared to the WBS. The performance ratios (ROE, ROA) reached negative values in 2010 and in 2011. They were also significantly lower than in the other countries. The indicator shows how effective banks are in earning income. The diversification of banking operations resulted in an increased profitability of the BSS banking sectors.

Liquidity is one of the most important financial objectives not only for any legal entity but also for banking markets. In this scope, the situation of the countries under comparison is rather clear - the BSS have lower liquidity than the WBS. The exception is Latvia, which faced the most serious consequences of the global financial crisis. The deposit value continues to grow with increasing speed, also thanks to decreased outflow. This offsets the decrease in foreign funding (e.g. in Croatia and Latvia). As a result, the LTD (loan-to-deposit) ratio fell below 100\% in the region, which indicates that domestic deposits have become the main source of funding for bank lending.

This proves that the banking sectors in the WBS need further reforms, especially with regard to supervising financial institutions, crisis resolution, financial safety nets, and the introduction of the Basel framework. Not only are they not able to keep pace with the EU member states like the BSS, but increasing their enforcement power is indispensable if they are to realise their EU membership hopes [Murgasova et al., 2015].

\section{Conclusions}

It must be stressed that there is no universal definition of banking stability. The literature proposes three approaches to this concept, viewing it in terms of the impact of the banking sector on other sectors and the macroeconomic situation, the quality of its functioning, or the lack of a crisis.

The article proves that despite being deeply affected by the global financial crisis, the banking sectors in the Baltic Sea states quickly recovered. This prompt improvement was a result of both international as well as domestic factors. As for the former, they established statehood in a peaceful neighbourhood, initiated a process of economic transformation, and have been members of the EU for over a decade, deepening the integration by adopting the euro. Among the domestic factors we should emphasise the quick and successful economic reform and transparency of policies. In the Western Balkan states, which also had to deal with the consequences of the global financial crisis, the postponed economic transformation, varying speeds of EU integration, and delayed recovery process have not 
contributed to an impressive improvement of the banking performance. The situation did not changed much over the studied period.

\section{References}

Acharya V.V., Drechsler I., Schnabl P., 2014, A pyrrhic victory? Bank bailouts and sovereign credit risk, Journal of Finance, no. 6.

Allen F., Gale D., 2000, Financial contagion, Journal of Political Economy, no. 1.

Allen W., Wood G., 2006, Defining and achieving financial stability, Journal of Financial Stability, no. 2.

Bałtowski M., Miszewski M., 2006, Transformacja gospodarcza w Polsce, Wydawnictwo Naukowe PWN, Warszawa.

Barker D., Holdsworth D., 1993, The causes of bank failures in the 1980s, Federal Reserve Bank of New York, Research Paper no. 9325.

Barr R., 2002, Evaluating the productive efficiency and performance of U.S. commercial banks, Engineering Management, no. 8.

Bartlett W., Monastiriotis V. (eds.), 2010, South Eastern Europe after the economic crisis: A new dawn or back to business as usual?, London School of Economics and Political Science LSE European Institute, London.

Bauer P.W., Berger A.N., Ferrier G.D., Humphrey D.B., 1998, Consistency conditions for regulatory analysis of financial institutions: A comparison of frontier efficiency methods, Journal of Economics and Business, no. 50.

Beck T., Demirguc-Kunt A., Levine R., 2006, Bank concentration, competition, and crises: First results, Journal of Banking Finance, no. 5.

Berger A.N., Bouwman C.H., 2013, How does capital affect bank performance during financial crises?, Journal of Financial Economy, no. 1.

Blok Z., 1993, Transformacja systemowa w Polsce. Wybrane problemy, Wydawnictwo Adam Marszałek, Poznań - Torun.

Bordo M., Eichengreen B., 1999, Is our current international economic environment unusually crisis prone?, [in:] Capital flows and the international financial system, eds. D. Gruen, L. Gower, Reserve Bank of Australia, Sydney.

Bretschger L., Kappel V., Werner T., 2012, Market concentration and the likelihood of financial crises, Journal of Banking Finance, no. 12.

Bromley D.W., 1993, Reconstituting economic systems: Institutions in national development, Development Policy Review, no. 2.

Chołaj H., 1998, Transformacja systemowa w Polsce. Szkice teoretyczne, Wydawnictwo Uniwersytetu Marii Curie-Skłodowskiej, Lublin.

Claessens S., Laeven, L., 2003, Financial development, property rights, and growth, Journal of Finance, no. 58 .

Cole R., 2012, How did the financial crisis affect small business lending in the United States?, US Small Business Administration, Technical Report 399.

Cole A., Pomerleau K., 2015, International tax competitiveness index 2015, Tax Foundation, https://files.taxfoundation.org/legacy/docs/TF_ITCI_2015.pdf [access: 01.10.2017].

Cox D., Cox M., 2006, The mathematics of banking and finance, John Wiley \& Sons, Ltd., New York. 
Crockett A., 1997, Why is financial stability a goal of public policy?, [in:] Maintaining financial stability in a global economy, symposium proceedings, Federal Reserve Bank of Kansas City.

Davis E.P., 2001, A typology of financial instability, Financial Stability Report no. 2, Oesterreichische Nationalbank.

Dell'Ariccia G., Detragiache E., Rajan R., 2008, The real effects of banking crises, Journal of Financial Intermediation, no. 7.

De Jonghe O., 2010, Back to the basics in anking? A micro-analysis of banking system stability, Journal Financial Intermediation, no. 3.

Djiwandono S., 1998, Banking system soundness and macroeconomic management: The recent Indonesian experience, symposium 'Towards the Restoration of Sound Banking Systems in Japan: Its Global Implication', International Monetary Fund.

EBRD, [n.d.], European Bank for Reconstruction and Development, online databases.

EC, 2011, European Commission, Progress Report for Croatia.

EC, 2014a, European Commission, Progress Report for Macedonia.

EC, 2014b, European Commission, Progress Report for Serbia.

EC, 2015a, European Commission, Progress Report for Macedonia.

EC, 2015b, European Commission, Progress Report for Serbia.

EC, 2016a, European Commission, Progress Report for Macedonia.

EC, 2016b, European Commission, Progress Report for Serbia.

Fernández R.O., Garza-García J.G., 2015, The relationship between bank competition and financial stability: A case study of the Mexican banking industry, Ensayos Revista de Economía, no. 1.

Fernández A.I., González F., Suárez N., 2013, The real effect of banking crises: Finance or asset allocation effects? Some international evidence, Journal of Banking Finance, no. 37.

Gemzik-Salwach A., 2013, Wptyw kryzysu finansów publicznych na stabilność sektora bankowego, Nierówności Społeczne a Wzrost Gospodarczy, nr 30.

Guitian M., 1997, Banking soundness: The other dimension of monetary policy, [in:] Banking Soundness and Monetary Policy, International Monetary Fund.

Jovanovic M., 1972, Yugoslav Trade With EEC and COMECON Countries, Law and Contemporary Problems, no. 37.

Kalemli-Ozcan S., Papaioannou E., Perri F., 2013, Global banks and crisis transmission, Journal of International Economy, no. 2.

King R.G., Levine R., 1993, Finance and growth: Schumpeter might be right, The Quarterly Journal of Economics, no. 3.

Klyvienë V., Tranberg Rasmussen L., 2010, Causes of financial crisis: The case of Latvia, Ekonomika, no. 2.

Kroszner R.S., Laeven L., Klingebiel D., 2007, Banking crises, financial dependence and growth, Journal of Financial Economy, no. 84.

Laeven L., Valencia F., 2013, Systemic banking crises database, IMF Economic Review, no. 2.

Larrain B., 2006, Do banks affect the level and composition of industrial volatility? Journal of Finance, no. 61.

Lepetit L., Nys E., Rous P., Tarazi A., 2008, Bank income structure and risk: An empirical analysis of European banks, Journal of Banking Finance, no. 8.

Levine R., 2005, Finance and growth: Theory and evidence, [in:] Handbook of economic growth, eds. P. Aghion, S. Durlauf, Elsevier Science, Amsterdam. 
Lingren C.J., Garcia G., Saal M., 1996, Banking system and macroeconomic policy, International Monetary Fund, Washington, DC.

Lucas R.E., 1988, On the mechanics of economic development, Journal of Monetary Economics, no. 1.

Miles D., Yang J., Marcheggiano G., 2013, Optimal bank capital, Economic Journal, no. 567.

Mirzaei A., Moore T., Liu G., 2013, Does market structure matter on bank's profitability and stability? Emerging vs. advanced economies, Journal of Banking Finance, no. 8.

Murgasova Z., Ilahi N., Miniane J., Scott A., Vladkova-Hollar I., 2015, The Western Balkans: 15 years of economic transition, International Monetary Fund, Washington, DC.

Raddatz C., 2006, Liquidity needs and vulnerability to financial underdevelopment, Journal of Financial Economy, no. 80.

Reinhart C.M., Rogoff K.S., 2009, This time is different: A panoramic view of eight centuries of financial crises, Princeton University Press, Princeton.

Sanfey P., Milatović J., Krešić A., 2016, How the Western Balkans can catch up, European Bank for Reconstruction and Development, Working Paper No. 185.

Sen A., Atlay H., 2012, The channels of contagion in the global crisis: The case of the South-Eastern Europe (SEE-7) countries, Journal of Economic and Social Studies, no. 2.

Smaga P., 2012, Powiąania między sektorem bankowym a kryzysem zadtużeniowym w strefie euro, Bezpieczny Bank, nr 3.

Staikouras C., Wood G., 2000, Competition and banking stability in the euro area: The cases of Greece and Spain, The Journal of International Banking Regulation, no. 2.

TRACE International, 2016, TRACE Matrix, https://www.traceinternational.org/trace-matrix [access: 01.10.2017].

Transparency International, 2016, Corruption Perceptions Index, https://www.transparency.org/news/feature/corruption_perceptions_index_2016 [access: 01.10.2017].

Vives X., 2010, Competition and stability in banking, IESE Working Paper No. 852.

Żywiecka H., 2012, Stabilność finansowa jako cel wspótczesnego banku centralnego, Bezpieczny Bank, nr 3.

K. Kubiszewska (『) kku@zie.pg.gda.pl Wydział Zarządzania i Ekonomii, Politechnika Gdańska, ul. G. Narutowicza 11/12, 80-233 Gdańsk, Polska 